\title{
FAKTOR-FAKOR DOMINAN YANG MEMPENGARUHI CALON MAHASISWA UNAI UNTUK MEMILIH UNAI DAN PROGRAM STUDI DI UNAI
}

\author{
Albinur Limbong, Ph.D. \& Dr. Horasdia Saragih M.Si. \\ Universitas Advent Indonesia
}

\begin{abstract}
Abstrak
Artikel ini adalah hasil penelitian yang dilakukan terhadap mahasiswa baru Unai angkatan 2014, 2015, 2016 dan 2017, tentang alasan mahasiswa memilih Unai untuk berkuliah. Tujuan penelitian ini adalah untuk mengetahui faktor-faktor dominan sehingga mahasiswa memilih Unai dan program studi pilihannya. Dengan mengetahui faktor-faktor dominan tersebut maka diharapkan menjadi masukan bagi pengambil keputusan untuk membuat program kerja untuk visi Unai bahwa pada tahun 2020 jumlah mahasiswanya akan menjadi 3000, naik dari sekitar 2000an sekarang ini. Hasil penelitian menunjukkan bahwa alasan mahasiswa memilih Unai adalah karena Unai adalah karena kampus berasrama dan program kerohaniannya (55.77\%), berkualitas dan berdisiplin $(25.57 \%)$, ada program berkuliah sambil bekerja $(17.40 \%)$, sedangkan sisanya $(12.87 \%)$ karena dekat rumah, dan alasan lainnya. Sementara alasan mahasiswa memilih program studinya adalah karena sesuai minat atau bakat $(53.60 \%)$, berkualitas dan gampang cari kerja $(33.55 \%)$, sedangkan sisanya $(12.85 \%)$ karena dorongan orang tua/saudara atau tidak ada pilihan lain di Unai. Faktor lain yang sangat menentukan bagi mahasiswa untuk memilih Unai maupun program studi di UNAI adalah karena akreditasi program studi di UNAI yang baik. Ada sebesar $88.10 \%$ mahasiswa mengatakan setuju atau sangat setuju bahwa akreditasi merupakan faktor penting bagi mereka untuk menentukan pilihannya. Namun perlu melalakukan penelitian lanjutan kepada siswa Advent yang tidak mau berkuliah di UNAI tentang alasan mereka tidak memilih Unai untuk berkuliah.
\end{abstract}

Kata-kata kunci: Mahasiswa, pendaftaran, akreditasi

\section{DOMINANT FACTORS INFLUENCING NEW STUDENTS TO CHOOSE UNAI}

\begin{abstract}
This paper is a result of a series of surveys conducted on the new students of Universitas Advent Indonesia (UNAI), batches 2014, 2015, 2016 and 2017, regarding the reasons of the students choosing UNAI to study. The purpose of the study is to see the dominant factors that influence the new students to choose UNAI and their preferred study programs. This information is expected to be a very important for the decision makers to make a strategic planning of how to achieve UNAI vision that in 2020 UNAI students will be 3000, increasing from around 2000 in 2017. The results show that there are three factors, namely: UNAI is a dormitory campus with religious programs (55.77\%), UNAI has a good quality and discipline (25.57) and UNAI has student labor or working education program (17.40\%), while the rest is because is near their house or other reasons (12.87\%). There are three reasons for the new students to choose the preferred study program, firstly because they are interested or talented in the study program (53.60\%), secondly the study program has good quality and easier to get job after graduation (33.5\%) and the rest is there is other preferred study programs available in UNAI and their parents asked them to study in UNAI (12.85\%). Another important factor for the new students to choose UNAI is because UNAI has a good accreditation level from government. $88.10 \%$ of the new students agree and even fully agree that the accreditation level of the preferred study program is very important factor for them to choose the study program. However, it is interested to study in the future why the
\end{abstract}


adventist students in West Indonesia Union Missions (estimated to be around 80\%) do not choose to study.

\section{Pendahuluan}

Universitas Advent Indonesia telah berdiri sejak tahun 1949, dan telah menamatkan lebih dari 11.000 alumni. Sekarang ini Unai memiliki visi menjadi universitas yang unggul di tingkat Divisi Asia Pasifik Selatan (SSD) diantara sesama perguruan tinggi advent yang berjumlah sekitar 24 perguruan Tinggi. Salah satu indikator untuk menjadi unggul adalah jumlah mahasiswa baru yang mendaftar setiap tahun dan jumlah mahasiswa yang tamat. Universitas Advent Indonesia terletak di Uni Indonesia kawasan Barat (UIKB) yang memiliki keanggotaan sekitar 100.000 orang. Peneliti menaksir bahwa ada sekitar 2500 orang anak advent yang ditamatkan pada tingkat sekolah menengah atas di wilayah UIKB. Namun disayangkan bahwa kurang dari $20 \%$ dari anak advent tersebut yang masuk ke Unai. Tujuan dari penelitian ini adalah untuk mengetahui faktor-faktor apa saja yang menentukan seorang mahasiswa untuk memilih Unai atau menentukan jurusan pilihannya. Dengan memahami faktor-faktor tersebut maka diharapkan dapat ditentukan strategi yang akan dilakukan untuk promosi dan menjalankan program akademik dan non-akademik di kampus Unai.

\section{Metodologi Penelitian}

Populasi dari penelitian ini adalah seluruh mahasiswa baru yang mengikuti kegiatan program studi dan pengenalan kampus (Ospek) untuk angkatan 2014, 2015 dan 2016 untuk program diploma-3 dan Sarjana. Dari 14 program studi yang ada di Unai ada 11 program studi (Akutansi, Manajemen, Sekretari, Keperawatan S1, Keperawatan D3, Filsafat, Biologi, Pendidikan Bahasa Inggris, Pendidikan Matematika, Sistem Informasi dan Teknik Informatika) yang wajib mengikuti ospek secara umum, sedangkan tiga program studi lainnya (Profesi Ners, Magister Filsafat dan Magister Manajemen) orientasi studi dilakukan secara khusus oleh program studi, karena untuk ketiga program studi ini mayoritas mahasiswa adalah alumni dari Unai, dan hanya yang bukan alumni Unai yang mengikuti orientasi yang bersifat khusus. Sampel dari penelitian ini adalah semua anggota populasi yang mengikuti program ospek. Walaupun angket dibagikan dan diharuskan diisi oleh semua peserta ospek namun tidak semua mengisi dan mengembalikan kertas angket ke panitia ospek. Pada tabel 1 berikut diberikan data populasi mahasiswa baru yang mengikuti ospek dan sampel atau jumlah peserta ospek yang mengembalikan angket setelah diisi. Dilihat bahwa secara total besar sampel $63.1 \%$ dari populasi, angka ini cukup besar untuk merepresentasikan populasi.

Tabel 1. Jumlah populasi dan sampel yang mengisi angket

\begin{tabular}{|l|l|l|}
\hline Angkatan & Populasi & Sampel (persentase) \\
\hline 2014 & 487 & $335(68.8 \%)$ \\
\hline 2015 & 517 & $168(32.5 \%)$ \\
\hline 2016 & 553 & $466(84.3 \%)$ \\
\hline 2017 & 462 & $304(65.8 \%)$ \\
\hline Total & 2.019 & $1.273(63.1 \%)$ \\
\hline
\end{tabular}

Angket yang dibagikan terdiri dari dua bagian. Yang pertama berisi tentang biodata mahasiswa yaitu tentang nama, jenis kelamin, agama, warganegara, alamat orang tua, asal sekolah, dan program studi pilihan di Unai. Bagian kedua adalah pertanyaan tentang dari mana tau Unai, mengapa memilih Unai, mengapa memilih program studi, apakah akreditasi program studi menentukan pilihannya, berapa rerata penghasilan orang tua, bagaimana penilaiannya tentang program ospek dan sistem pendaftaran online, dan saran-saranya. Opsi jawaban diberikan 4 opsi untuk dipilih, namun diberikan opsi kelima yaitu opsi terbuka dimana mahasiswa diminta menuliskan jawabannya sendiri di luar 4 opsi yang diberikan. 


\section{Hasil Penelitian}

\section{Agama Mahasiswa}

Pada gambar 1 ditunjukkan persentase jumlah mahasiswa baru Unai yang beragama Advent dan Non-Advent (Islam, Protestan, Katolik, Budha dan Hindu).

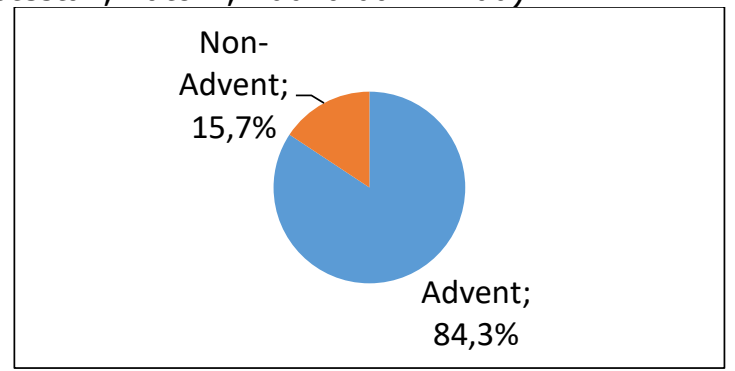

Gambar 1. Persentase mahasiswa baru yang beragama Advent dan non-Advent di UNAI.

Dapat dilihat pada gambar bahwa mahasiswa Advent ada sebanyak 84.3\%, sedangkan mahasiswa non-Advent hanya $15.7 \%$. Sebenarnya ada variasi kecil dari persentase mahasiswa Advent dan non-Advent dari tahun 2014 hingga 2017. Angka pada gambar adalah rerata persentase untuk empat tahun terakhir.

Sedangkan untuk keseluruhan mahasiswa UNAI secara rata-rata mahasiswa Advent ada sebanyak $88 \%$, dan non-Advent hanya $12 \%$. Perbedaan yang kecil, sekitar $3.7 \%$, adalah karena ada sebagian mahasiswa yang non-Advent akhirnya dibaptis menjadi Advent setelah berkuliah di UNAI, dan kebanyakan baptisan tersebut terjadi pada tahun pertama perkuliahannya.

\section{Asal Sekolah}

Pada gambar 2 diberikan data persentase mahasiswa baru Unai yang tamat dari sekolah Advent atau non-Advent. Seperti untuk data pada gambar 1, ada variasi kecil dari persentase asal tamatan, sekolah Advent atau non-Advent, mahasiswa baru UNAI dari tahun 2014 hingga 2017. Sehingga angka yang diberikan pada gambar adalah rerata persentase untuk empat tahun terakhir.

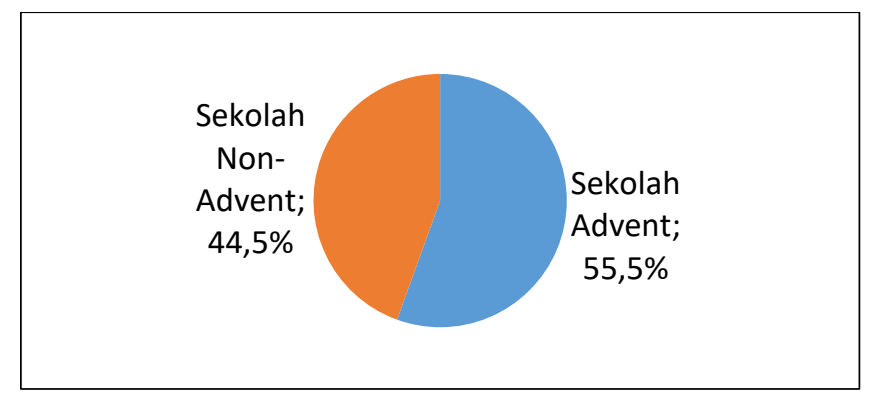

Gambar 2. Persentase mahasiswa baru UNAI yang tamat dari sekolah Advent dan non-Advent.

Dari gambar 2 dapat dilihat bahwa ada 55.5\% mahasiswa baru UNAI tamat dari sekolah Advent, sedangkan sisanya (45.5\%) tamat dari sekolah non-Advent. Bila dibandingkan dengan data pada gambar 1 , ini berarti bahwa ada sebanyak $28.8 \%$ mahasiswa baru UNAI yang beragama Advent tidak sekolah di sekolah Advent untuk sekolah lanjutan atasnya. Bila pilihan mahasiswa untuk bersekolah di sekolah Advent mengindikasikan kepercayaannya kepada sekolah Advent, maka dapat disimpulkan bahwa ada sekitar $28.8 \%$ siswa Advent yang masuk ke UNAI tetapi tidak percaya kepada pendidikan Advent di sekolah menengah Atas, tetapi percaya kepada UNAI.

Pada saat penulis mengadakan promosi ke sekolah-sekolah Advent dan menanyakan data-data persentase orang advent di sekolah-sekolah Advent yang penulis kunjungi didapati bahwa secara ratarata kurang dari $50 \%$ dari siswa yang bersekolah di sekolah Advent yang beragama Advent. Bahkan ada sekolah Advent yang siswanya di atas 1000 orang untuk sekolah menengah pertama dan atas tetapi 
anak advent kurang dari $10 \%$. Namun Angka ini masih jauh lebih baik dari data yang diberikan oleh Departemen Pendidikan Divisi Asia Pasifik Selatan bahwa kurang dari 5\% anak Advent bersekolah di sekolah Advent.

Ada beberapa kemungkinan alasan mengapa orang Advent tidak menyekolahkan anaknya di sekolah Advent. Kemungkinan pertama adalah karena sekolah advent jauh dari rumahnya. Untuk sekolah dasar atau menengah pertama orang tua cenderung menyekolahkan anaknya di sekolah yang tidak terlalu jauh dari rumahnya tetapi berkualitas. Namun untuk sekolah menengah atas orang tua sudah mulai menyekolahkan anaknya ke sekolah yang lebih jauh dari rumahnya apalagi kalau sekolah tersebut berasrama dan berkualitas. Untuk mahasiswa, orang tua sudah mulai rela melepas anaknya bersekolah di tempat yang jauh untuk tingkat perguruan tinggi seperti UNAI, tetapi kualitas tetapi menjadi bahan pertimbangan orang tua.

\section{Asal daerah}

Pada gambar 3 diberikan data persentase mahasiswa baru UNAI menurut asal daerahnya. Seperti untuk data pada gambar 1 dan 2, ada variasi kecil dari data tersebut untuk tahun 2014 hingga 2017. Sehingga angka yang diberikan pada gambar 3 adalah rerata persentase untuk empat tahun terakhir.

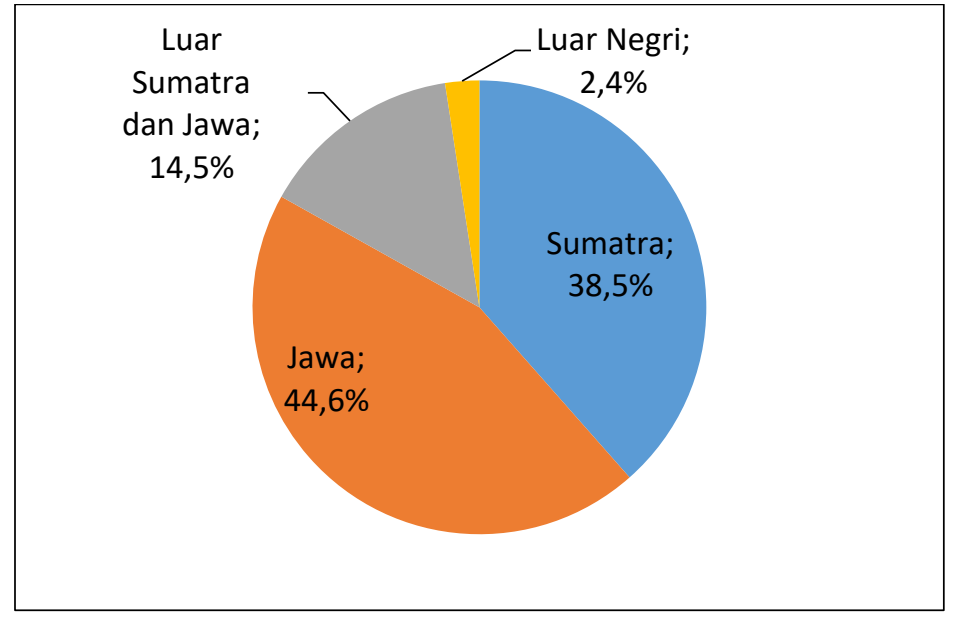

Gambar 3. Daerah asal mahasiswa baru UNAI.

Dapat dilihat pada gambar 3 ada sebanyak $44.6 \%$ mahasiswa baru UNAI berasal dari Pulau Jawa, $38.5 \%$ berasal dari Pulau Sumatra, dan sisanya $14.5 \%$ berasal dari pulau lain di Indonesia, dan 2.4\% berasal dari luar Negri seperti Malaysia, China, Timor Leste dan Amerika. Ini berarti bahwa mayoritas calon mahasiswa baru dipasok dari Pulau Jawa dan Sumatra. Ini dapat dimengerti karena Gereja Masehi Advent Hari Ketujuh Uni Indonesia Kawasan mayoritas anggotanya ada di Pulau Sumatra dan Jawa.

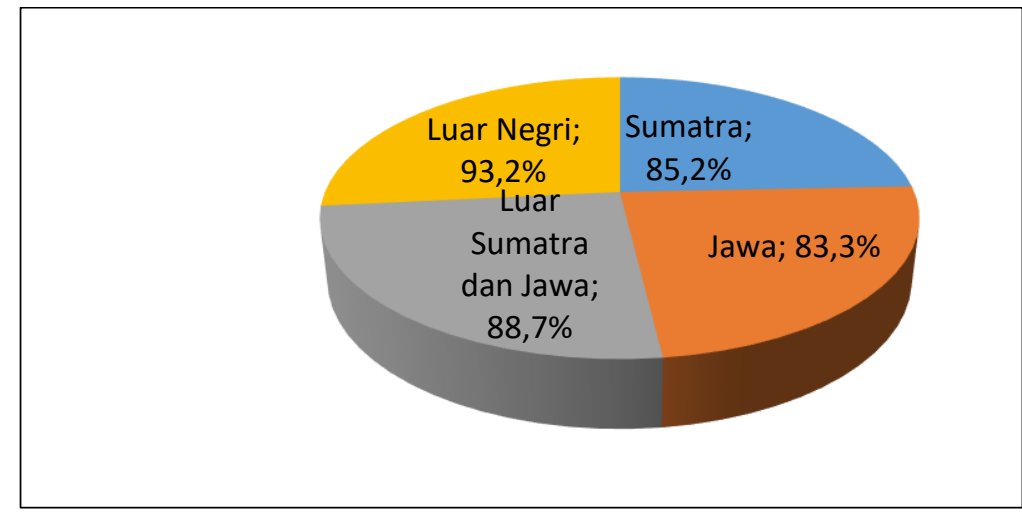

Gambar 4. Persentase mahasiswa baru UNAI yang beragama Advent dari berbagai Daerah. 
Pada gambar 4 ditunjukkan data persentase mahasiswa baru Unai yang beragama Advent yang berasal dari berbagai dari di Indonesia maupun luar negri. Data pada gambar 4 adalah angka rata-rata untuk tahun 2014 hingga 2017. Dilihat dari gambar 4 bahwa UNAI yang berlokasi di Bandung atau Pulau Jawa memiliki mahasiswa baru beragama Advent yang berasal dari Pulau Jawa lebih sedikit persentasenya dibanding dari Sumatra, Luar Sumatra dan Jawa dan Luar Negri. Ini dapat dimengerti bahwa orang Advent akan lebih berani merantau berkuliah ke UNAI sekalipun daerahnya jauh dari UNAI. Data ini juga dapat mengindikasikan bahwa lebih baik berpromosi ke sekolah Advent yang ada di Pulau Jawa daripada luar Jawa, karena orang advent yang ada di Luar Jawa akan tetap datang ke UNAI karena lebih memilih pendidikan Advent dan lebih berani merantau,

\section{Sumber informasi tentang Unai}

Pada gambar 5 ditunjukkan data tentang sumber informasi tentang Unai bagi mahasiswa baru. Sumber informasi tentang Unai kebanyakan diperoleh mahasiswa dari keluarga atau saudara atau sahabatnya (63.4\%), kemudian diikuti oleh Sekolah atau gereja Advent $(25.98 \%)$, sisanya $(10.63 \%)$ melalui internet/situs web Unai atau lain-lain (misalnya tetangga).

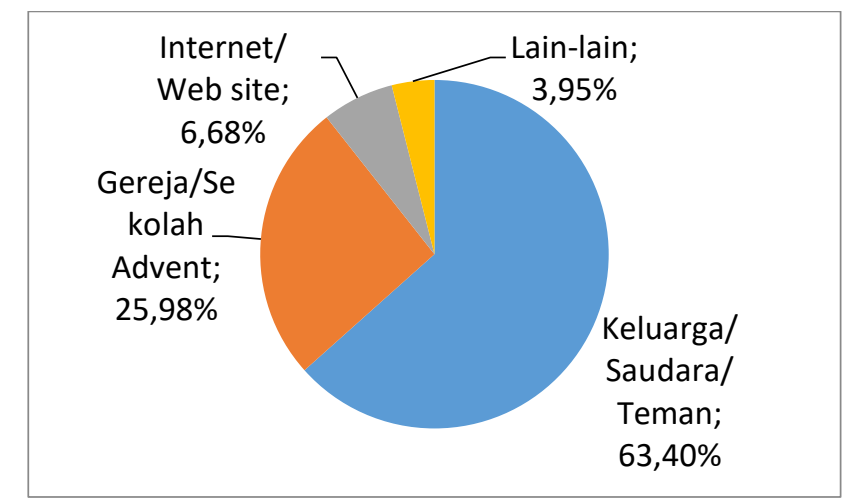

Gambar 5. Sumber informasi bagi mahasiswa mengenai Unai

Keluarga/Saudara/teman merupakan sumber paling dominan bagi mahasiswa untuk mengetahui lebih banyak tentang perguruan tinggi yang akan dia tuju untuk berkuliah. Khususnya untuk keluarga yang merupakan alumni Unai maka perbincangan mengenai Unai atau program studi di Unai akan banyak diperoleh oleh calon mahasiswa dari keluarganya (ayah/ibu/saudaranya).

Tabel 2. Sumber Informasi tentang UNAI bagi mahasiswa Advent dan Non-Advent tahun 2017

\begin{tabular}{|l|r|r|}
\hline Sumber Informasi & \multicolumn{1}{|c|}{ Advent } & \multicolumn{1}{l|}{ Non-Advent } \\
\hline Keluarga/Saudara/Teman & $69 \%$ & $80 \%$ \\
\hline Gereja/Sekolah Advent & $25 \%$ & $10 \%$ \\
\hline Internet/Web site & $1.50 \%$ & $5 \%$ \\
\hline Lain-lain & $4.50 \%$ & $5 \%$ \\
\hline
\end{tabular}

Adalah menarik untuk mengetahui perbandingan data-data di atas pada tabel 2 untuk mahasiswa advent dan non-Advent. Pada tabel xx ditunjukkan perbandingan data antara mahasiswa Advent dan non-Advent tentang sumber informasi tentang UNAI untuk mahasiswa angkatan 2017. Untuk keluarga non-Advent faktor keluarga ini sedikit lebih tinggi persentasenya (80\%) dibanding 
keluarga Advent (69\%), kedua adalah dari sekolah Advent dimana mereka bersekolah (10\%). Data ini menunjukkan bahwa promosi ke sekolah-sekolah Advent cukup penting dilakukan untuk menarik perhatian siswa non-Advent.

\section{Alasan Memilih Unai}

Pada gambar 6 ditunjukkan data alasan mahasiswa memilih UNAI. Sebenarnya ada sedikit variasi data dari tahun ke tahun, dan data pada gambar adalah rerata persentase untuk empat tahun survei yaitu 2014, 2015, 2016 dan 2017. Dalam survei ini mahasiswa diminta untuk memilih hanya salah satu opsi jawaban saja, yaitu yang paling dominan bagi mereka untuk memilih UNAI sebagai tempat berkuliah. Pada opsi lain-lain mahasiswa diminta untuk menuliskan sendiri alasannya, namun mahasiswa yang memilih opsi lain-lain ini hampir semuanya tidak menuliskan jawabannya. Bilamana mahasiswa tidak menjawab pertanyaan ini, disengaja atau tidak, maka jawaban mahasiswa dikelompok juga kepada opsi lain-lain.

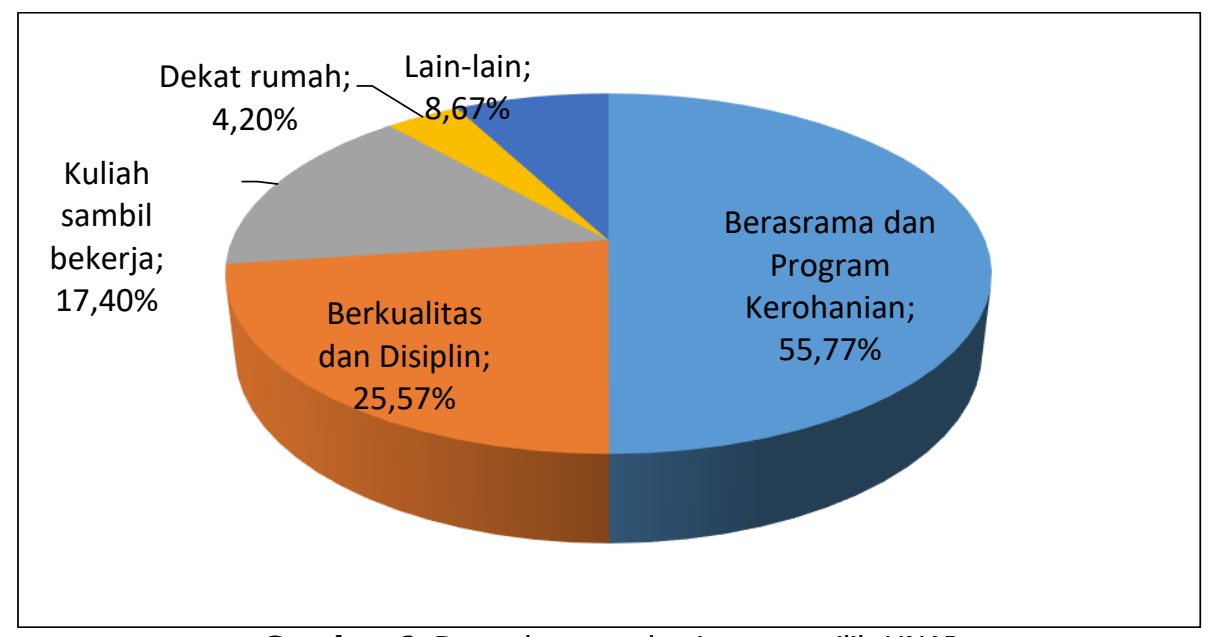

Gambar 6. Data alasan mahasiswa memilih UNAI

Dari gambar dapat dilihat bahwa alasan terbesar mengapa mahasiswa memilih Unai adalah karena UNAI adalah sekolah berasrama dan adanya program kerohanian yang baik $(55.77 \%)$. Alasan kedua terbesar adalah karena UNAI dinilai berkualitas (25.57\%) dengan disiplin yang baik. Alasan ketiga adalah adanya program berkuliah sambil bekerja (17.40\%).

Mahasiswa yang datang ke UNAI karena Unai berasrama dan ada program kerohanian yang rutin akan diharapkan akan mengikuti segala peraturan asrama dan akan menikmati segala kegiatankegiatan kerohanian. Besar kemungkinan kelompok yang $55.77 \%$ ini adalah mahasiswa yang tidak akan melakukan pelanggaran aturan2 kemahasiswaan yaitu absensi di kebaktian-kebaktian dan check room asrama dan lain-lain. Dengan kata lain diduga kuat bahwa kelompok tidak akan mendapat hukuman daftar ulang oleh karena masalah asrama atau absensi kegiatan kerohanian. Juga diperkirakan bahwa kelompok ini akan lebih mulus perkuliahannya di UNAI dan akan tamat tepat waktu.

Mahasiswa yang memilih UNAI karena alasan berkualitas dan berdisiplin boleh jadi karena mereka melihat bahwa banyak alumni UNAI yang memiliki karir dan gaji yang baik, cepat mendapatkan pekerjaan atau boleh jadi karena akreditasi atau ranking UNAI yang cukup baik. Tingkat keberhasilan mereka dari UNAI boleh jadi tidak semulus orang yang masuk dikelompok pertama di atas (yaitu kelompok 55.77\%), karena kalaupun mereka secara akademik sangat baik tetapi jika melakukan pelanggaran-pelanggaran di asrama dan di setiap kebaktian, maka akan menghambat kelancaran studi mereka dan boleh jadi akan tamat tepat waktu.

Mahasiswa yang memilih UNAI karena alasan adanya program bekerja sambil berkuliah diduga kuat adalah kelompok mahasiswa yang kemampuan ekonomi orang tuanya kurang, sehingga mengharapkan bekerja di UNAI untuk dapat berkuliah dan menyelesaikan studinya di UNAI. Kelompok 
ini diyakini akan relatif menurut kepada aturan asrama atau kegiatan-kegiatan kerohanian, dan satusatunya faktor yang membuat mereka akhirnya droped-out atau tidak tamat dari UNAI adalah karena hutangnya terlalu besar karena gaji dari student labor tidak sanggup lagi menutupi besarnya hutang yang dimiliki.

\section{Alasan Memilih Program Studi}

Pada gambar 7 ditunjukkan data alasan mahasiswa memilih program studi pilihannya di UNAI untuk mahasiswa baru tahun 2014 hingga 2017. Ada sedikit variasi data dari tahun ke tahun, data pada gambar adalah rerata persentase untuk empat tahun survei.

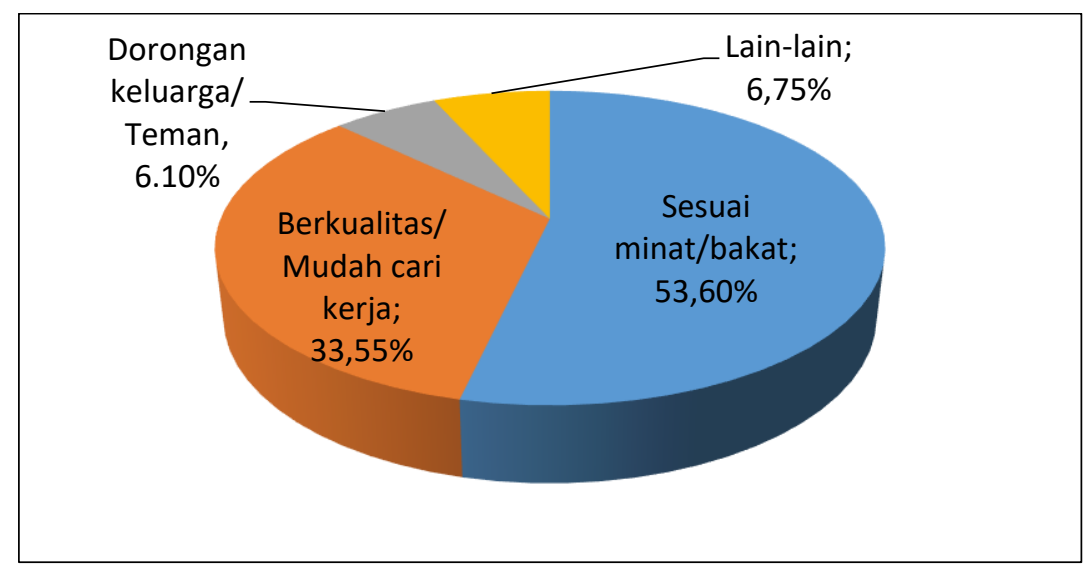

Gambar 7. Data alasan mahasiswa memilih Program studi di UNAI.

Pada survei mahasiswa diminta hanya memilih satu opsi saja dari empat pilihan empat opsi yang diberikan yaitu karena sesuai minat/bakat, karena berkualitas/mudah mencari pekerjaan, karena didorong keluarga atau diajak teman, atau alasan lain. Pada opsi alasan lain diminta kepada mahasiswa untuk menuliskannya, tetapi kebanyakan mahasiswa tidak menuliskan alasan memilih opsi lain-lain. Jika mahasiswa mengosongkan jawaban, atau tidak memilih sama sekali, maka jawaban tersebut akan dikelompokkan kepada pilihan lain-lain.

Mayoritas mahasiswa mengatakan bahwa alasan mereka memilih program studi yang akan diambil karena sesuai dengan minatnya atau bakatnya (63.7\% pada tahun 2016 atau $39.5 \%$ pada tahun 2017). Alasan yang kedua terbesar adalah karena program studi tersebut berkualitas dan tamatannya gampang cari kerja (28.6\% pada tahun 2016 atau 34.5\% pada tahun 2016). Alasan ketiga mahasiswa memilih program studi yang dituju adalah karena didorong oleh orang tua atau keluarga. Ada juga mahasiswa mengaku bahwa sebenarnya program studi pilihannya, yaitu sesuai minat atau bakatnya, tidak ada di UNAI, namun karena dia harus berkuliah di UNAI, mungkin karena dipaksa atau didorong orang tua, maka dia mengambil program studi yang ada di UNAI.

\section{Pengaruh Akreditasi dalam menentukan pilihan}

Salah satu isu penting yang ingin diketahui adalah apakah akreditasi program studi adalah salah satu faktor penting bagi mahasiswa untuk menentukan pilihan ke program studi atau tidak. Pertanyaan ini baru dimasukkan ke angket untuk mahasiswa baru angkatan 2017, sehingga data ini tidak tersedia untuk angkatan 2014, 2015 dan 2016. Pada gambar 8 ditunjukkan persentase mahasiswa yang sangat setuju, setuju, tidak setuju dan tidak perduli dengan pendapat bahwa akreditasi merupakan faktor penentu untuk memilih program studi di UNAI. 


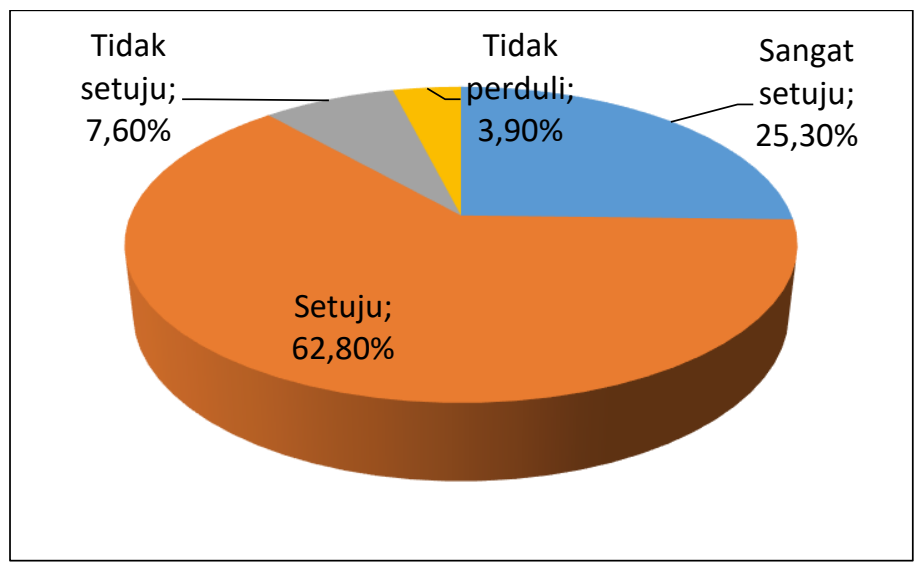

Gambar 8. Faktor Akreditasi dalam mementukan pilihan masuk ke UNAI

Dari gambar dapat dilihat bahwa mayoritas mahasiswa setuju $(62.80 \%)$ dan bahkan sangat setuju (25.30\%) bahwa akreditasi merupakan faktor penting bagi mereka untuk menentukan pilihan ke Unai atau ke program studi. Memang ada sekitar $13.5 \%$ mahasiswa tidak setuju dengan pendapat tersebut bahkan tidak perduli dengan tingkat akreditasi UNAI atau program studi. Pada kuesioner ini tidak ditanyakan lebih lanjut kepada yang menjawab sangat setuju atau setuju bahwa sekiranya akreditasi UNAI kurang baik dari level akreditasi sekarang ini, apakah mereka akan tetap datang ke UNAI? Namun hasil di atas cukup kuat mengindikasikan bahwa jika akreditasi program studi di UNAI tidak baik maka jumlah mahasiswa UNAI akan berkurang dari yang mendaftar saat ini, dengan kata lain akreditasi sangat penting untuk menaikkan jumlah mahasiswa UNAI.

\section{Promosi ke sekolah Advent}

Setiap tahun pimpinan Unai atau tim promosi UNAI akan mengadakan promosi ke seluruh sekolah lanjutan atas Advent yang ada di Uni Indonesia kawasan Barat. Adalah menarik untuk mengetahui seberapa besar pengaruh dari kunjungan ke sekolah-sekolah Advent bagi calon mahasiswa baru. Survei ini dilakukan kepada mahasiswa baru angkatan 2016, dimana ada 4 opsi pilihan diberikan yaitu pengaruh keluarga/saudara, gereja/sekolah, mahasiswa/staf dosen Unai, dan promosi ke sekolah. Pada saat promosi UNAI ke sekolah-sekolah advent siswa diberikan informasi-informasi yang lebih deteil tentang Unai, yang membuat hati siswa semakin diteguhkan agar mereka memilih Unai. Khususnya bagi mereka yang kurang/tidak mampu, dimana mereka mengandalkan program bekerja sambil berkuliah agar dapat berkuliah di UNAI, maka dengan promosi Unai informasi kebijakan tersebut dapat disampaikan lebih jelas.

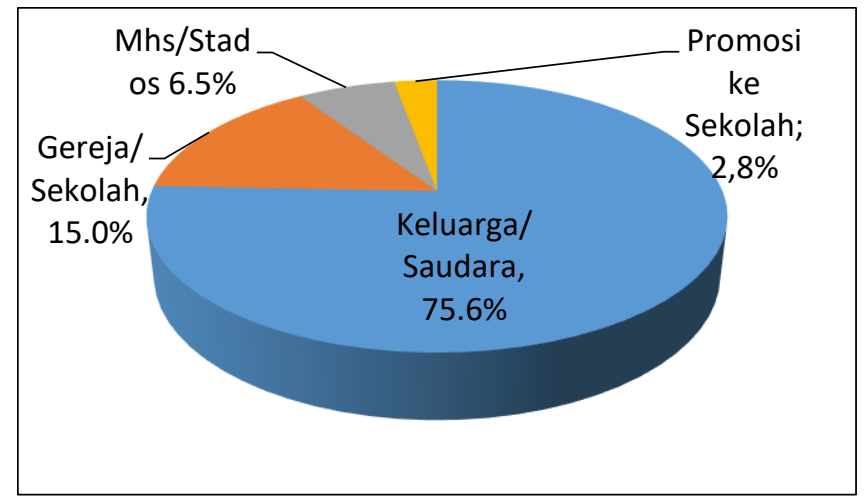

Gambar 9. Sumber promosi bagi mahasiswa baru untuk menentukan pilihan ke UNAI. 
Pada gambar 9 di atas diberikan data persentase mahasiswa memilih masuk ke Unai atas pengaruh dari keluarga/saudara, gereja/sekolah, mahasiswa/staf dosen Unai atau promosi sekolah. Yang paling besar pengaruhnya adalah keluarga/saudara (75.61\%), diikuti oleh pengaruh gereja/sekolah (15.04\%) dan mahasiswa/staf dosen Unai (6.50\%). Survei menunjukkan bahwa pengaruh survei ke sekolah-sekolah Advent hanya sekitar 3\%. Hasil survei ini dapat mengindikasikan bahwa jika sekiranya promosi Unai tidak dilakukan ke sekolah-sekolah Advent maka potensi kehilangan mahasiswa hanya sekitar 3\%. Promosi yang paling efektif dilakukan bukanlah kunjungan ke sekolahsekolah Advent tetapi adalah dengan meningkatkan kualitas akademik dan pelayanan kemahasiswaan sehingga orang akan berbicara mulut ke mulut melalui keluarga/saudara, atau melalui gereja (pendeta)/sekolah (guru-guru).

\section{Diskusi}

Dengan jumlah anggota Gereja Masehi Advent Hari Ketujuh di Uni Indonesia Kawasan barat sekitar 100.000 orang, maka diprediksi bahwa setiap tahunnya ada paling tidak sekitar 2.500 orang anak Advent yang menamatkan pendidikan di level sekolah menengah atas. Jika seluruh anak Advent ini masuk ke UNAI maka mahasiswa UNAI akan ada sebanyak 10.000 orang (karena ada 4 angkatan yang berkuliah). Namun faktanya hanya sekitar 1.700 hingga 1.800 orang anak Advent yang berkuliah di UNAI, atau kurang dari $20 \%$ anak Advent berkuliah di UNAI, sisanya, sebagian kecil ada berkuliah di PTASN (Perguruan Tinggi Advent Surya Nusantara) di Pematang Siantar, di Universitas Klabat (UnKlab) di Manado atau ke luar negri (seperti Adventist University of the Phillippines (AUP), dan sebagian besar (sekitar 80\%) berkuliah di perguruan tinggi non-Advent di Indonesia atau di luar negri.

Fakta menunjukkan bahwa cukup signifikan persentase/jumlah mahasiswa yang mengatakan bahwa dia memilih program studi karena sesuai minatnya atau bakatnya, maka perlu mengetahui program studi apa saja yang diminati oleh calon mahasiswa/stakeholder UNAI. Dengan membuka program studi yang sesuai dengan minat/bakat calon mahasiswa Advent. Level akreditasi program studi merupakan salah satu faktor penting bagi mahasiswa untuk memilih program studi di UNAI. Namun tidak berarti bahwa jika beberapa program studi memiliki level akreditasi sama maka daya tarik mahasiswa kepada program studi tersebut akan sama. Daya tarik mahasiswa terhadap suatu program studi sangat bergantung kepada minat atau bakat mahasiswa dan kesempatan kerja bagi mahasiswa setelah menamatkan pendidikannya kelak. Jika suatu program studi, sekalipun itu favorit, mengalami penurunan tingkat akreditasinya besar kemungkinan akan semakin rendah daya tarik mahasiswa untuk memilih program studi tersebut. Penurunan tingkat akreditasi suatu program studi akan berpengaruh kepada kesempatan bagi mahasiswa untuk mencari kerja di kemudian hari, khususnya untuk beberapa pekerjaan sebagai pegawai pemerintah atau pegawai negri sipil, dimana dipersyaratkan bahwa calon pelamar harus tamat dari perguruan tinggi dengan akreditasi program studi dengan tingkat baik atau lebih.

\section{Kesimpulan dan Saran}

Dari hasil penelitian yang dijelaskan di atas dapat diambil kesimpulan bahwa faktor-faktor yang paling dominan yang membuat mahasiswa baru Unai memilih Unai sebagai tempat berkuliah adalah karena Unai berasrama dan program pembinaaan kerohanian $(55.77 \%)$, dan karena Unai dinilai berkualitas dan mahasiswa dituntut berdisiplin (25.57\%). Alasan ketiga mahasiswa Unai adalah karena adanya program kuliah sambil bekerja(17.40\%), dimana disamping mendapat uang untuk membantu meringankan biaya kuliahnya, mahasiswa dibekali dengan kecakapan/ketrampilan, dan disiplin/etika bekerja. Sedangkan faktor dominan yang menentukan mahasiswa memilih program studi pilihannnya di Unai adalah karena sesuai minat/bakatnya (53.60\%), diikuti karena berkualitas dan mudah cari kerja saat tamat nanti ( $33.55 \%)$. Faktor lain yang menentukan mahasiswa memilih program studi adalah tingkat akreditasi program studi tersebut, dimana $62.80 \%$ mahasiswa mengatakan setuju, atau $25.30 \%$ mengatakan sangat setuju bahwa akreditasi merupakan faktor penting bagi mereka untuk menentukan pilihannya. 
Promosi UNAI ke sekolah-sekolah Advent juga merupakan sarana untuk mempengaruhi calon mahasiswa untuk datang ke UNAI, hanya dampaknya tidak cukup signifikan. Hanya 3\% dari mahasiswa mengatakan bahwa mereka datang ke UNAI oleh karena promosi ke sekolah-sekolah mereka. Kesimpulan di atas adalah berdasarkan survei kepada mahasiswa baru UNAI yang datang berkuliah di UNAI. Namun adalah menarik untuk mengetahui apa alasan anak-anak Advent yang tidak berkuliah ke perguruan tinggi Advent, menurut anak itu sendiri atau menurut orang tua mereka. Jika misalnya mereka tidak datang ke UNAI oleh karena jurusan itu tidak ada di UNAI, dan jumlah mereka cukup signifikan untuk kelayakan membuka sebuah program studi baru maka Unai perlu membuka program studi baru tersebut. Karena itu perlu dibuat penelitian lanjutan tentang apa faktor-faktor yang membuat siswa Advent sehingga tidak mau berkuliah di Unai atau perguruan tinggi Advent lainnya.

\section{Referensi}

1. Agni Alam Wirya, Indah Piliyanti, 2009. "Penggunaan Analisis Faktor untuk menentukan Kriteria Pemilihan Program Studi Ekonomi Islam". EKBISI, 4(1), 85-97.

2. Fernandez Jacqueline Liza, 2010. "An explanatory study of factors influencing the decision of students to study at universiti sains Malaysia". Kajian Malaysia, 28(2).

3. Kusumawati Andriani, 2010. "Privatization and marketization of Indonesian public universities: a systematic review of student choice criteria literature Research Online Sydney Business School Papers".

4. Mashur Razak, 2008. "Analisis proses pengambilan keputusan mahasiswa dalam memilih program studi pada PTS di Sulawesi Selatan". social and culture, reference group, marketing communication, 5(2): 89-102.

5. Md, Samsinar, Sidin Siti Rahayu Hussin, Tan Ho Soon, 2003. "An Exploratory Study of Factors Influencing the College Choice Decision of Undergraduate Students in Malaysia". Asia Pacific Management Review, 8(3), 259-280.

6. Wagner, K. \& Fard, P. Y., 2009. "Factors Influencing Malaysian Students' Intention to Study at a Higher Educational Institution". Chinese American Scholars Association, New York, New York, USA, Retrieved 11 July 2009, from http://www.gcasa.com/PDF/malaysia/Wagner- Fard.pdf

7. Yoseph Kee Ming Sia, 2011. "Post Secondary Student' Behaviour in the College Choice Decision". Journal of Marketing Research \& Case Studies Curtin University. 